\title{
Formation of Extensional Basin in Internal Part of the Zag-Ros Orogeny in West of Sirjan, Iran
}

\author{
Amin Azadikhah'1, Soheila Bouzari', Ali Yassaghi' ${ }^{2}$, Mohammad Hashem Emami ${ }^{3}$ \\ ${ }^{1}$ Department of Geology, North Tehran Branch, Islamic Azad University, Tehran, Iran \\ ${ }^{2}$ Department of Geology, Tarbiat Modares University, Tehran, Iran \\ ${ }^{3}$ Department of Geology, IslamShar Branch Islamic Azad University, Islamshhar, Iran \\ Email: aminazadikhah@yahoo.com
}

Received 7 October 2015; accepted 27 November 2015; published 30 November 2015

Copyright (C) 2015 by authors and Scientific Research Publishing Inc.

This work is licensed under the Creative Commons Attribution International License (CC BY). http://creativecommons.org/licenses/by/4.0/

(c)

\begin{abstract}
Oblique continent-continent collision between Iranian microcontinent and Arabian plate is the main cause of transpression and transtension regimes in this area. Zagros orogeny in this area resulted in formation of various structures including thrust fault-related folds, dextral and sinistral, strike slip faults, normal fault related to dextral strike slip fault. Thrust faults within the area under study are duplex with general trend of NW-SE and dip toward the north-east with right slip component. Strike slip fault regime acts as tear fault and it is active yet. Therefore, simultaneous presence of thrusts and strike slip faults illustrates convergent dextral transpressional tectonic regime while this transpressional regime accompanied with transtension as well; since normal faults are also seen in alluvium around depression of Sirjan which can be as a result of extension stresses due to strike slip faults activity of the district. The results achieved from geometry and kinematic analysis of west of Sirjan structures indicate that structures of the area have characteristics of internal part of Zagros orogeny.
\end{abstract}

\section{Keywords}

Zagros Orogeny, Thrust Faults, Transpression, Strike Slip Faults

\section{Introduction}

From tectonic point of view, the region under study has been located in internal part of Zagros orogeny and southern part of Sanandaj-Sirjan metamorphic zone. Due to convergence and collision of central Iranian microcontinent with Arabian plate and followed by Neotethys ocean closure, Zagros orogeny belt has been created [1]-[8]. Beginning point 
of Arabian-Eurasia collision along with Zagros suture is estimated in upper-cretaceous, [9] and Paleocene [10].

Orogenies often consist of an internal part with more value of shortening and an external part with less value of deformation [11] [12]. Transpression deformation [13] resulted from simultaneous presence of strike slip shear and shear vertical to shortening and was an important style of deformation in areas with oblique convergence [14]-[17]. The aim of the study is to identify all important structures of west Sirjan region which has important role in creation of present deformations and morphology of the area. These structures, using data obtained from the field studies and geological maps, analyzed from geometric and kinematic point of view, and finally, their structural evolution has been deduced.

\section{Geological Framework}

Geographically the studied area is located in western areas of Sirjan (Figure 1) and from structural geology point of view, the area is counted as a part of Zagros orogeny (Sanandaj-Sirjan zone). Lithological units of Sanandaj-Sirjan area are generally belong to Paleozoic, Mesozoic and Cenozoic age. These units have already been driven by thrusts with piggy back style, from NE toward SW [3].

In Zagros orogeny, magmatic belt of Orumieh-Dokhtar and Sananandaj-Sirjan zone counted as internal part of orogeny [9]; [18] and folded belt-thrust as external part of orogeny [3] [18].The region under study is located in southern part of Sanandaj-Sirjan structural zone.

\section{Structural Specifications}

The most important structures existed in the region are thrusts, normal faults, strike slip faults and folds (Figure 1). The most important structures which have more appearance in the region and identified \& studied in present research include Gol Gohar-Baghat thrust with $50 \mathrm{~km}$ length, NW-SE strike and dip direction toward NE. This thrust has caused shiest units and recrystallized limestone with Ordovician Cambrian thrust on Jurassic units. The style of this thrust corresponded with leading imbricate fan .Chahe Badam thrust has NW-SE trend with dip toward NE and it has $15 \mathrm{~km}$ length. This thrust cause marble units of Devonian thrusted over Jurassic turbidite units. Style of the thrust has corresponded with Antiformal stack duplex pattern. This thrust indicates dextral strike slip component, therefore it is oblique. Baghe Nasar has approximate trend of N315 with relative vertical dip, dip direction toward SW and app. $35 \mathrm{~km}$ length. The thrust caused Oligo-miocene conglomerate units to

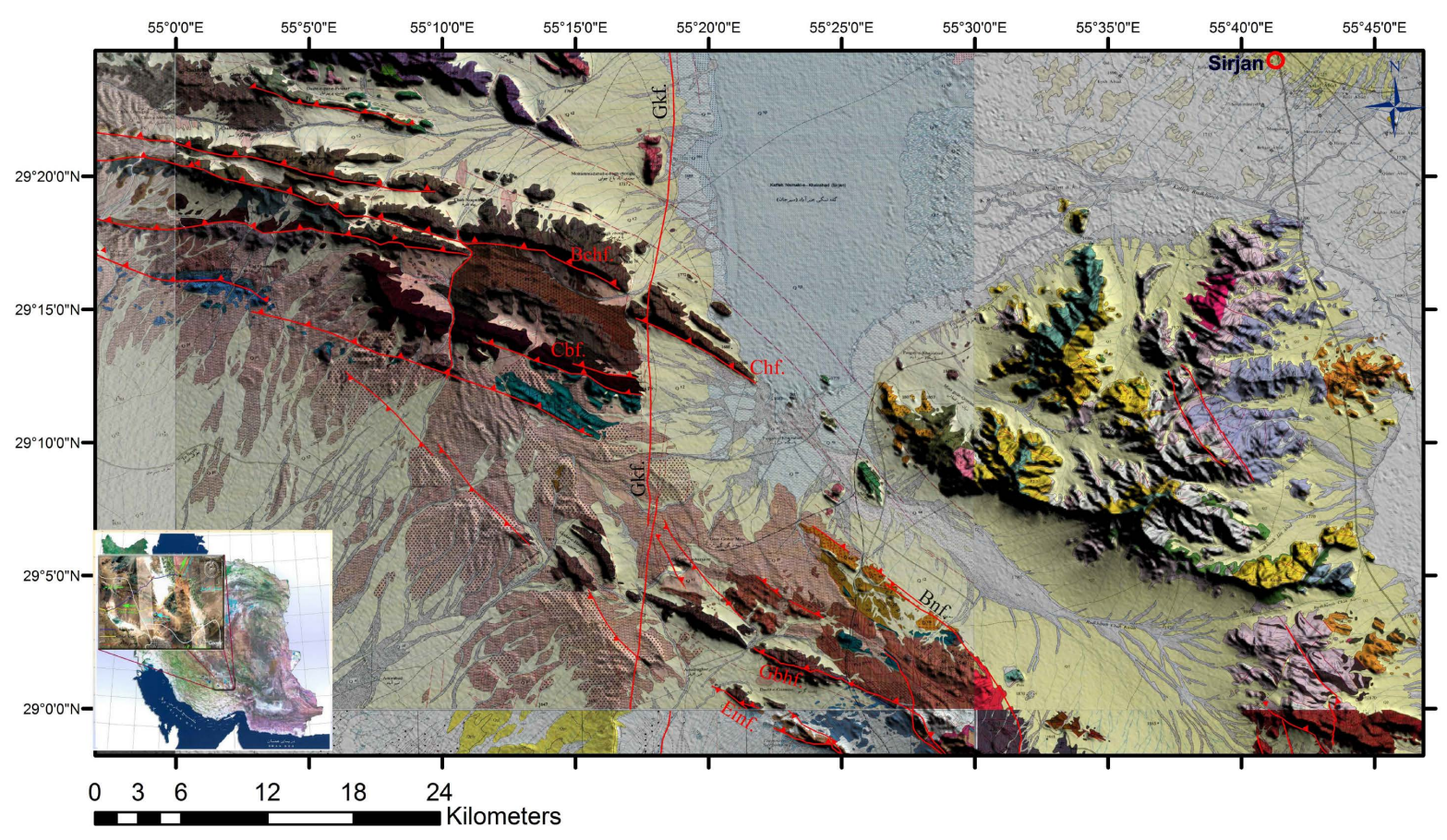

Figure 1. Map of the main fault areas, Gkf: Gole Gohar-Kheirabad fault, Chf: Chah meil fault, Cbf: Chahbadam fault, Bnf: Baghe nasr fault, Einf: Einolbaghar fault, Gole Gohar Baghat fault, Bchf: Baghe chobi fault. 
thrust over recent alluvial. Chahe Meil thrust has approximate trend of N302 with dip direction toward NE and app. $9 \mathrm{~km}$ length. Style of the thrust has corresponded with duplex Antiformal stack. This thrust caused permocarboniferous limestone units to thrust over recent alluviums.

Baghe Choobi thrust: this thrust has general strike of N290 and its dip direction is toward NE. style of the thrust has corresponded with Antiformal stack duplex pattern. This thrust is also indicated a dextral strike slip component and, hence, it is oblique. Baghe Choobi thrust caused limestone and permo-carboniferous units to be thrusted over alteration basalts pillow lava of middle Triassic (Figure 1). It has approximately $34 \mathrm{~km}$ length. Ayn Al Bagar thrust has general trend of N300, dip direction toward NE and $9.5 \mathrm{~km}$ length. This thrust has caused shiest units \& recrystallized limestone with Ordovician-Cambrian age thrust over Jurassic turbidites units. Style of the thrust has corresponded with leading imbricate fan pattern. Quaternary thrust caused Quaternary alluviums to thrust and tilt. strike slip thrust, in the region under study, consists of Gol Gohar-Kheir Abad fault zone which includes the zone of dextral strike slip fault with general trend of North-South and app. length of $115 \mathrm{~km}$, has been located parallel to each other with En Echelon pattern (Figure 1 \& Figure 2 \& Figure 3).

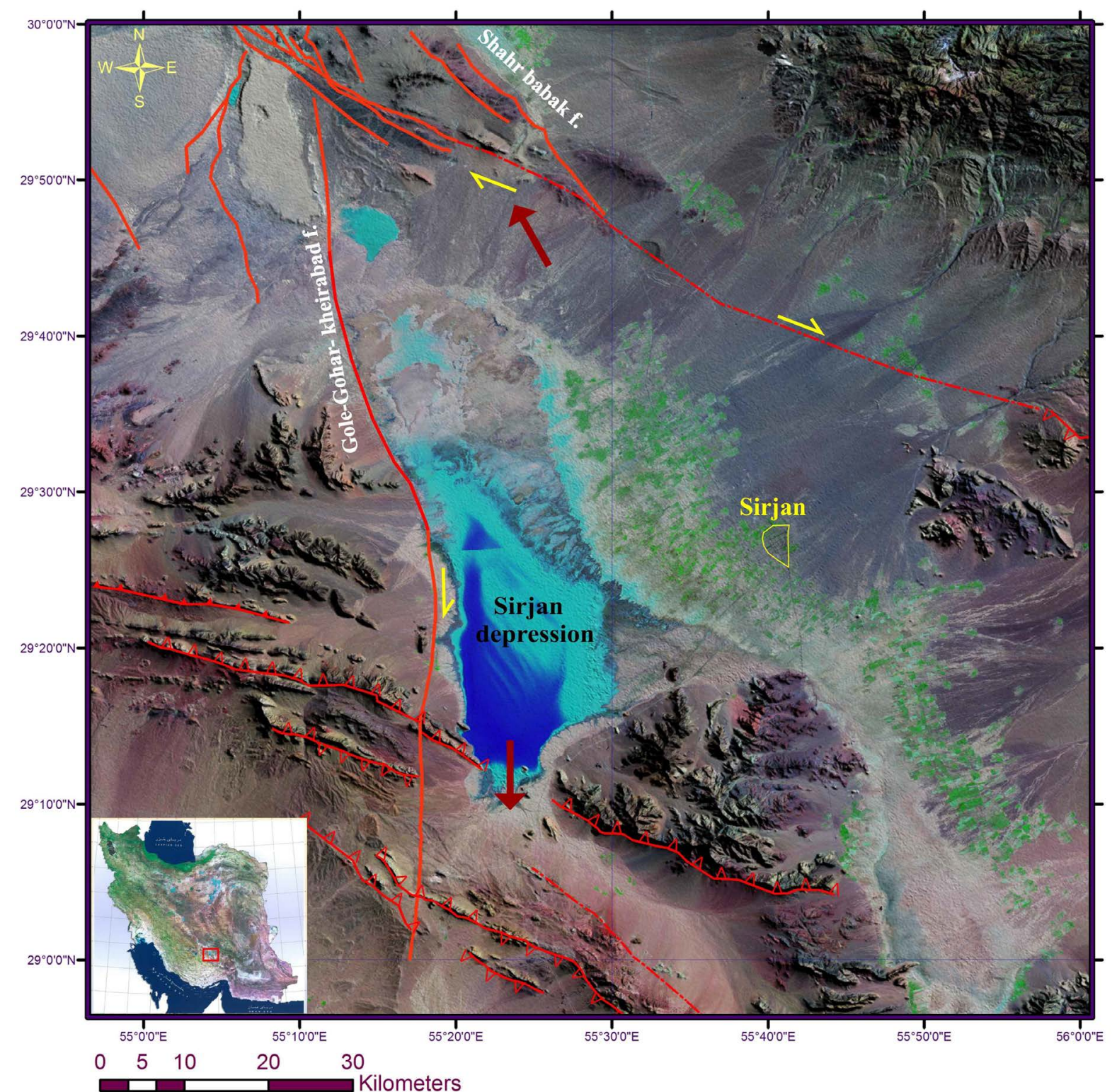

Figure 2. The landsat ETM satellite image that show the most important strike slip fault zones, Gole gohar Kheirabad fault and Shahr babak fault that play important role in the formation of Sirjan depression. 


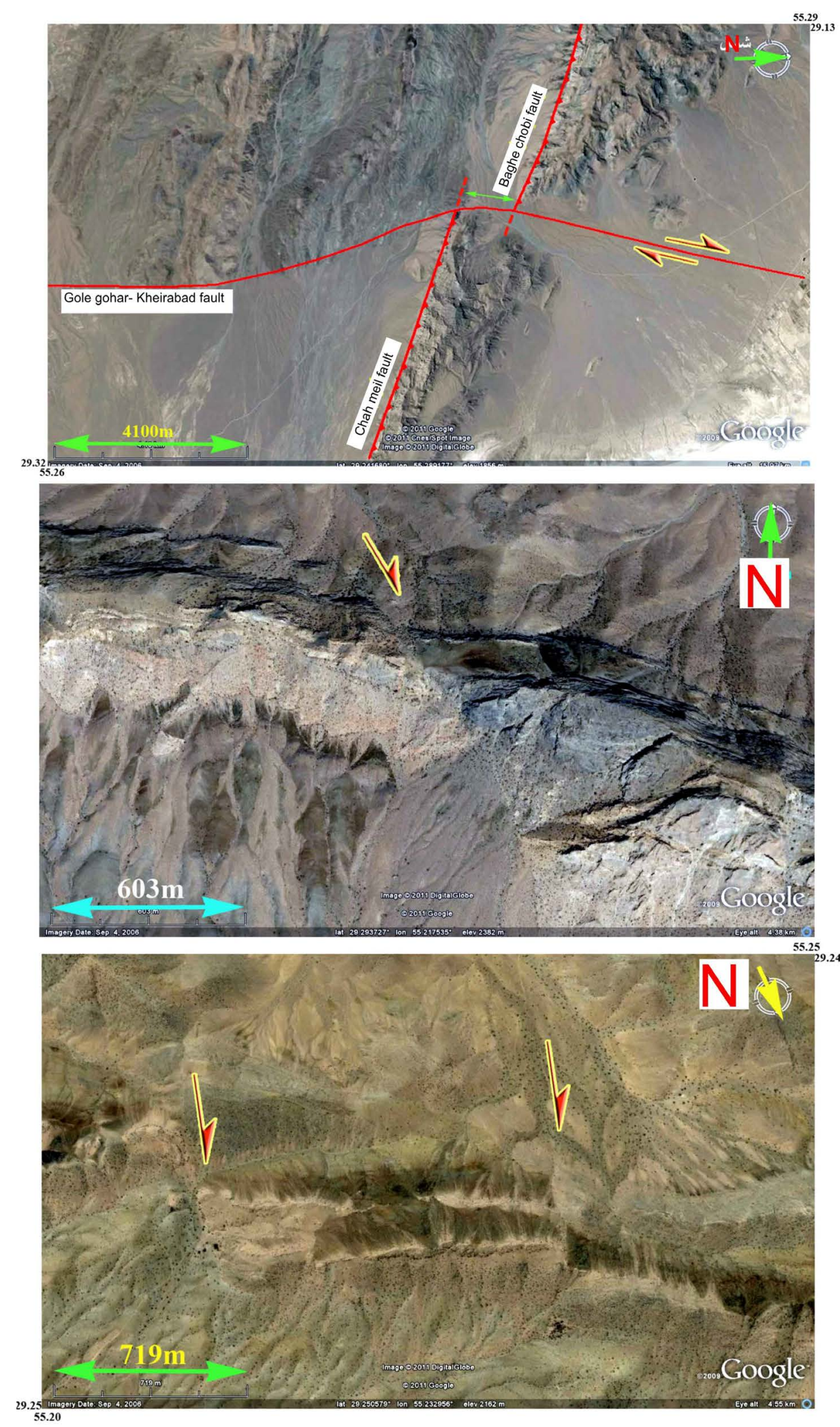

Figure 3. The landsat ETM satellite image that show the most important strike slip fault zones, Gole gohar Kheirabad fault and Shahr babak fault that play important role in the formation of Sirjan depression. 
Southern plains of Sirjan depression covered by recent alluvium and involved in offset \& deformation by various normal faults which have also a dextral strike slip component (Figure 4). The trend of majority of the normal faults is N300 which is parallel to trend of thrust and reverse structures in the region (Figure 4). In the region under study, folds have axis with NW-SE trend and axial plane with dip direction toward NE, created as a result of thrusts activities \& developed and located in hanging wall of these thrust.

\section{Discussion}

\subsection{Tectonic Evolution}

Neotethys Ocean closure in South-East from late Jurassic influenced Sananadaj-Sirjan zone [6] and deformed the sediments with prevailing maximum stress direction of NE-SW. Oblique collision of NE edge of Arabian plate with Sananadaj-Sirjan zone along of Zagros suture in early cretaceous is the factor of establishing dextral convergence transpression tectonic regime on this zone [6]. Arabian plate counterclockwise rotation caused transpressional tectonic after opening of Red Sea.

In this area, there was a magmatic sedimentary basin during Paleozoic and early Mesozoic in which sediments, mainly from turbidite type, accumulated and this basin was very active from magmatic activity point of view. The basin is incomparable with Paleozoic platforms of other parts of Iran such as Zagros and central Iran, therefore, the basin was rather deeper than the platform due to having very active margins ultramafic magmas activities and mafic in this basin were abundant and, hence, unlike the platforms, it has too thin cover and asthenosphere beneath these basins which was too higher than the border in platforms [19].

Typical Imbricate structure of the region has been formed within the same early Cimmerian orogeny and these structures are, indeed, the same extension structures formed in extension phenomena which were applied in early Cimmerian inversion tectonic phases and created thrust napes [19]. A new extension phase has been appeared between middle \& upper Triassic, evidence of which can be continental flood basalt. These exposures illustrate a new extension phase in early upper Triassic which have made depressions in the margin of Paleozoic and early Mesozoic metamorphic belt, in fact presence of Jurassic turbidities and flysches are considered suitable
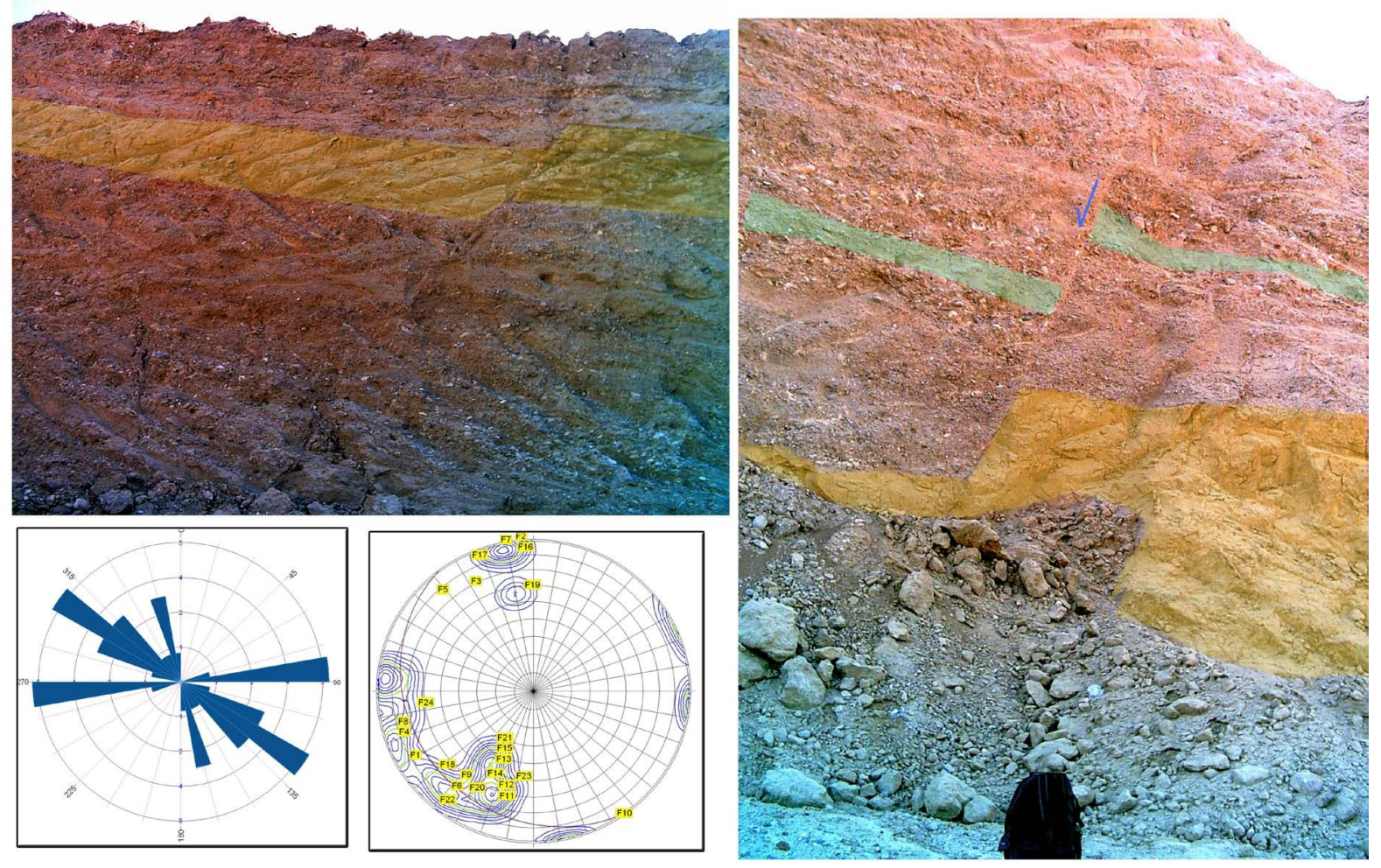

Figure 4. Dextral displacement with Gole gohar Kheirabad strike slip fault zone in the west of Sirjan depression. 
evidence. All lithological units prior to Cretaceous were folded and uplifted in Laramid orogeny phase in late cretaceous and formed mountains, erodes of which accumulated in Eocene flysch basins. In young phases of Alp, Eocene flysches were folded and resulted erodes has formed molasses. Marin transgression on the past units has created limestone reef of Oligomiocene, Qom formation. Present structural situation of the region is due to uplift \&erosion phases of Pleistocene.

\subsection{Evidences Transpression and Transtension Regime}

Structural evidences and kinematic analysis of thrust zones in west of Sirjan area illustrate that these thrust faults developed during Zagros orogeny. Geometry of these thrust zones has conformity with structures of internal part of Zagros orogeny. In this region Oblique thrust zones show tranpression regime. Strike slip faults are most dextral and less sinistral with north - south striking (Figure 2 \& Figure 3). The strike slip faults have normal component (Figure 4). The normal and strike slip faulting have newest activity in this region. The co existence of normal and strike slip faulting illustrate transtension regime.

\subsection{Sirjan Depression Formation}

Sirjan depression is located in west of Sirjan city that cover by recent evaporate sediments such as salt and clay. Structural evidences and kinematic analysis of strike slip fault zones in west of Sirjan area illustrate that these strike slip faults have an important role in the formation of Sirjan depression. The most important fault zones that play a role in the formation of Sirjan depression are Kheirabad-Golegohar fault zone and Shahrbabk fault zone (Figure 2). This depression is located in the east of Kheirabad-Golegohar fault zone (Figure 2). This is a dextral strike slip fault and have north-south striking with normal component (Figure 4). The east portion of Kheirabad-Golegohar fault zone moves to south (Figure 2). The Shahrbabak fault zone is a dextral strike slip fault and has north west-south east striking with reverse component and dip direction to the south west. The southwest portion of Shahrbabak fault zone moves to northwest (Figure 2). The region between two fault zones has a triangle shape and is lower than the surrounding area. The activity of these fault zones lead to formation of Sirjan depression. In south of Sirjan depression some normal faults cut recent alluvium (Figure 4). This normal faults have dextral strike slip component and have north west-south east striking (Figure 4).

\section{Conclusion}

The most important structures of the area under the study are thrusts, geometry of which is similar to those of duplex structures. Structures with such geometric characteristics are usually formed within internal part of orogenies. However, the dip direction of the most structures of western and southern areas of Sirjan is toward North-Northeast. The analysis of Kinematic indicators of the area indicates that structure formation of the area is interrelated to Zagros orogeny. As a result, this area can be an internal part of Zagros orogeny known as Sananadaj-Sirjan zone. In this area, the mechanisms of strike slip faults are more dextral type and less sinistral which cut and displaced the thrusts of study area and their characteristics conformed to tear faults. Recent activity of the dextral strike slip faults caused tension faults formation, normal type, in location of realizing bend of the strike slip fault. Coexistence of dextral strike slip faults beside thrust faults indicates transpression tectonic regime and normal strike slip faults indicate transtension regime. Magmatic activities, from pillow lava type, as well as basalt flow in Paleozoic units indicate existence of a magmatic-sedimentary basin during Paleozoic time that controlled by normal faults. Thrust structures of the area are those normal structures that transformed into the area thrusts in inversion tectonic during early Cimmerian phase and reactivated during following tectonic phases due to Arabian \& Iranian plates collision. The most important stage of the area thrust structures activity belongs to middle Miocene, i.e. simultaneous with continental collision. The activity of two strike slip fault zones, Kheirabad-Golegohar fault zone and Shahrbabak fault zone lead to formation of Sirjan depression.

\section{References}

[1] Agard, P., Omrani, J., Jolivet, L. and Mouthereau, F. (2005) Convergence History across Zagros (Iran). Constraints from Collisional and Earlier Deformation. International Journal of Earth Sciences, 94, 401-419.

http://dx.doi.org/10.1007/s00531-005-0481-4 
[2] Agard, P., Omrani, J., Jolivet, L., Whitechure, H. and Vrielynck, B. (2011) Zagros Orogeny: A Subduction-Dominated Process. Geological Magazine, 148, 692-725.

[3] Alavi, M. (1994) Tectonics of the Zagros Orogenic Belt of Iran: New Data and Interpretations. Tectonophysics, 229, 211-238. http://dx.doi.org/10.1016/0040-1951(94)90030-2

[4] Alavi, M. (1980) Tectonostratigraphic Evolution of the Zagrosides of Iran. Geology, 8, 144-149. http://dx.doi.org/10.1130/0091-7613(1980)8<144:TEOTZO>2.0.CO;2

[5] Besse, J., Torcq, F., Gallet, Y., Ricou, L.E., Krystyn, L. and Saidi, A. (1998) Late Permian to Late Triassic Palaeomagnetic Data from Iran: Constraints on the Migration of the Iranian Block through the Tethyan Ocean and Initial Destruction of Pangaea. Geophysical Journal International, 135, 77-92. http://dx.doi.org/10.1046/j.1365-246X.1998.00603.x

[6] Mohajjel, M., Fergusson, C.L. and Sahandi, M.R. (2003) Cretaceous-Tertiary Convergence and Continental Collision, Sanandaj-Sirjan zone, Eastern Iran. Journal of Asian Earth Sciences, 21, 397-412. http://dx.doi.org/10.1016/S1367-9120(02)00035-4

[7] Mohajjel, M. and Rasouli, A. (2014) Structural Evidence for Superposition of Transtension on Transpression in the Zagros Collision Zone: Main Recent Fault, Piranshahr Area, NW Iran.

[8] Paul, A., Kaviani, A., Hatzfeld, D., Vergne, J. and Mokhtari, M. (2006) Seismological Evidence for Crustal-Scale Thrusting in the Zagros Mountain Belt (Iran). Geophysical Journal International, 166, 227-237. http://dx.doi.org/10.1111/j.1365-246X.2006.02920.x

[9] Berberian, M. and King, G.C.P. (1981) Towards a Paleogeography and Tectonic Evolution of Iran. Canadian Journal of Earth Sciences, 18, 210-285. http://dx.doi.org/10.1139/e81-019

[10] Allen, M., Jackson, J. and Walker, R. (2004) Late Cenozoic Reorganization of the Arabia Eurasia Collision and the Comparison of Short-Term and Long-Term Deformation Rates. Tectonics, 23, TC2008.

[11] Hatcher, R.H. and Williams, R.T. (1986) Mechanical Model for Single Thrust Sheets: Part I, Taxonomy of Crystalline Thrust Sheets and Their Relationships to the Mechanical Behavior of Orogenic Belts. Geological Society of America Bulletin, 97, 975-985. http://dx.doi.org/10.1130/0016-7606(1986)97<975:MMFSTS>2.0.CO;2

[12] Twiss, R. and Moores, E. (1992) Structural Geology. W.H. Freeman and Company, New York.

[13] Harland, W.B. (1971) Tectonic Transpression in Caledonian Spitsbergen. Geological Magazine, 108, 27-42. http://dx.doi.org/10.1017/S0016756800050937

[14] Jones, R.R., Holdsworth, R.E., Clegg, P., McCaffrey, K. and Tavarnelli, E. (2004) Inclined Transpression. Journal of Structural Geology, 26, 1531-1548. http://dx.doi.org/10.1016/j.jsg.2004.01.004

[15] Lin, S., Jiang, D. and Williams, P.F. (1998) Transpression (or Transtension) Zones of Triclinic Symmetry: Natural Example and Theoretical Modelling. In: Holdsworth, R.E., Strachan, R.A. and Dewey, J.F., Eds., Continental Transpressional and Transtensional Tectonics, Geological Society of London, London, 41-57. http://dx.doi.org/10.1144/gsl.sp.1998.135.01.04

[16] Sanderson, D.J. and Marchini, W.R.D. (1984) Transpression. Journal of Structural Geology, 6, 449-458. http://dx.doi.org/10.1016/0191-8141(84)90058-0

[17] Teyssier, C., Tikoff, B. and Markley, M. (1995) Oblique Plate Motion and Continental Tectonics. Geology, 23, 447-450. http://dx.doi.org/10.1130/0091-7613(1995)023<0447:OPMACT>2.3.CO;2

[18] Nemati M. and Yassaghi A. (2010) Structural Characteristics of the Transitional Zone from Internal to External Parts of the Zagros Orogen, Iran. Asian Journal of Earth Sciences, 39, 161-172.

[19] Sabzehei, M., Roshan Ravan, B., Eshraghi, S. and Seraj, M. (1994) Geological Map of the Gole Gohar. Scale: 1:100,000, Geological Survey of Iran, Tehran, Iran. 